\title{
Editorial
}

\section{Hypocalcemia with imatinib treatment in chronic myeloid leukemia patients}

\author{
Iffat Jamal ${ }^{1, *}$ \\ ${ }^{1}$ Dept. of Hematology, Indira Gandhi Institute of Medical Sciences, Patna, Bihar, India
}

\section{A R T I C L E I N F O}

Article history:

Received 28-06-2021

Accepted 06-07-2021

Available online 23-11-2021
This is an Open Access (OA) journal, and articles are distributed under the terms of the Creative Commons Attribution-NonCommercial-ShareAlike 4.0 License, which allows others to remix, tweak, and build upon the work non-commercially, as long as appropriate credit is given and the new creations are licensed under the identical terms.

For reprints contact: reprint@ipinnovative.com

\section{Introduction}

Imatinib mesylate is a tyrosine kinase inhibitor targeted to BCR-ABL, PDGFR, and KIT mutations. It plays a pivotal role in treatment of chronic myelogenous leukaemia (CML) and gastrointestinal stromal tumours (GISTs), and has dramatically changed the clinical management of these tumour types. ${ }^{1-4}$

The adverse effects of imatinib are mostly mild and manageable.

Various side effects are as follows:
1. Anemia
2. Oedema
3. Fatigue
4. Nausea
5. Diarrhoea
6. Cramps
7. Rash
8. Myalgia
9. Arthralgia
10. Granulocytopenia

Musculoskeletal effects of imatinib are reported in $25 \%$ of GIST patients and 20-40\% of CML patients, including arthralgia, myalgia, and muscle cramps, but are rarely doselimiting. ${ }^{2,5-8}$

\footnotetext{
* Corresponding author.

E-mail address: iffatjamal111@gmail.com (I. Jamal).
}

The pathophysiology of these effects is uncertain. Various pathophysiological mechanisms proposed are :

1. Firstly, although KIT is expressed on renal tubular cells, their functions there are unknown. Imatinib could therefore be exerting a direct effect on renal tubular KIT receptors, resulting in relative hypocalcaemia.

2. Secondly, imatinib is a member of a family of protein tyrosine kinase inhibitors which can induce marked changes in cell excitability and ion homeostasis. Indeed, imatinib blocks low voltage-activated Ttype calcium channels in human embryonic kidney cells. ${ }^{9}$ Thus imatinib could have a nonspecific effect on calcium homeostatsis that is not KIT receptormediated.

3. Thirdly imatinib might be causing nonspecific inhibition of calcium channels in tubule which might be leading to hypocalcemia.

Musculoskeletal complaints are a common side effect of imatinib and are manifested as muscle cramps and bone pain. The muscle cramps occur mainly in the hands, feet, calves, and thighs. The pattern, frequency, and severity of cramps are usually constant over time, and they may resemble titanic contractions. Some patients relate cramps to exertion or describe night time occurrence. Bone pain and arthralgias have been reported by $20 \%$ to $40 \%$ of patients. Their onset tends to be in the first month of therapy, and they frequently abate after a few months. The symptoms most frequently affect the femurs, tibias, hips, and knees. 
Bone or joint pain can be severe and disabling and may be strikingly asymmetric. In some cases, imaging studies were done but failed to detect abnormalities.

Various electrolyte imbalances common in imatinib treatment

1. Hypophophatemia: This is the most common electrolyte imbalance associated with imatinib. The clinical manifestations of mild hypophosphatemia include myalgias, weakness, anorexia. Chronic severe depletion may be manifested by pain in muscles and bones.

2. Hypocalcemia: This is the second most common abnormality which was detected in patients onimatinib, hypocalcemia increases excitation of nerve and muscle cells, primarily affecting the neuromuscular and cardiovascular systems. Extensive spasm of skeletal muscle causes cramps and tetany. ${ }^{9}$

3. Hypokalemia: Described only in case reports in patients who are on imatinib, this is also a possible cause of myalgia and muscle spasms but does not cause arthralgia /bony pains.

The treatment which has been advised by NCCN and other literature evidence states that calcium supplementation is an important treatment aspect in the management of musculoskeletal pain along with fluids supplementation. ${ }^{10,11}$

\section{Conclusion}

Myalgia and musculoskeletal is the one of the common nonhematological side effect in patients of chronic myeloid leukemia who are initiated on imatinib. This side effect must be efficiently taken care of inorder to increase the compliance of patients for better outcome.

\section{Conflict of Interest}

None.

\section{References}

1. Joensuu H, Fletcher C, Dimitrijevic S, Silberman S, Roberts $P$, Demetri G. Management of malignant gastrointestinal stromal tumours. Lancet Oncol. 2002;3(11):655-64.

2. Deininger MW, O'brien SG, Ford JM, Druker BJ. Practical management of patients with chronic myeloid leukemia receiving imatinib. J Clin Oncol. 2003;21(8):1637-47.

3. O'brien SG, Guilhot F, Larson RA. Imatinib compared with interferon and low-dose cytarabine for newly diagnosed chronic-phase chronic myeloid leukemia. New Engl J Med. 2003;348(11):994-1004.

4. Blay JY, Bonvalot S, Casali P. Consensus meeting for the management of gastrointestinal stromal tumors. Ann Oncol. 2005;16(4):566-78.

5. Demetri GD, Mehren MV, Blanke CD. Efficacy and safety of imatinib mesylate in advanced gastrointestinal stromal tumors. New Engl J Med. 2002;347(7):472-80.

6. Verweij J, Casali PG, Zalcberg J. Progression-free survival in gastrointestinal stromal tumours with high-dose imatinib: randomised trial. Lancet. 2004:364:1127-34.

7. Debiec-Rychter M, Dumez H, Judson I, Wasag B, Verweij J, Brown $\mathrm{M}$, et al. Use of c-KIT/PDGFRA mutational analysis to predict the clinical response to imatinib in patients with advanced gastrointestinal stromal tumours entered on phase I and II studies of the EORTC Soft Tissue and Bone Sarcoma Group. Eur J Cancer. 2004;40(5):689-95.

8. Talpaz M, Silver RT, Druker BJ, Goldman JM, Gambacorti-Passerini $\mathrm{C}$, Guilhot $\mathrm{F}$, et al. Imatinib induces durable hematologic and cytogenetic responses in patients with accelerated phase chronic myeloid leukemia: results of a phase 2 study. Blood. 2002;99(6):1928 37.

9. Marin D, Marktel S, Bua M, Armstrong L, Goldman JM, Apperley JF, et al. The use of imatinib (STI571) in chronic myelod leukemia: some practical considerations. Haematologica. 2002;87(9):979-88.

10. Cataldi M, Gaudino A, Lariccia V, Russo M, Amoroso S, Renzo $\mathrm{G}$, et al. Imatinib-mesylate blocks recombinant T-type calcium channels expressed in human embryonic kidney-293 cells by a protein tyrosine kinaseindependent mechanism. J Pharmacol Exp Ther. 2004;309(1):208-15. do1:10.1124/jpet.103.061184.

11. Blay JY, Berthaud P, Perol D, Ray-Coquard I, Bui B, Braud F, et al. Continuous vs intermittent imatinib treatment in advanced GIST after one year: a prospective randomized trial of the French Sarcoma Group. Proc Am Soc Clin Oncol. 2004;22(14):9006.

\section{Author biography}

Iffat Jamal, Assistant Professor

Cite this article: Jamal I. Hypocalcemia with imatinib treatment in chronic myeloid leukemia patients. Indian J Pathol Oncol 2021;8(4):431-432. 